\title{
The UNCLOS Dispute Settlement System: What Role Can It Play in Resolving Maritime Disputes in Asia?
}

\author{
Lan Ngoc NGUYEN ${ }^{1}$ \\ University of Cambridge, United Kingdom \\ lnn21@cam.ac.uk
}

\begin{abstract}
Asia is currently the scene of some of the most high-profile maritime disputes in the world. Even though the majority of States in Asia are parties to the United Nations Convention on the Law of the Sea ("UNCLOS"), its dispute settlement system has only been utilized in a handful of cases. Given that negotiations have brought about limited result in easing many of the tensions, it is worth asking whether the UNCLOS dispute settlement system can play a role in the resolution of maritime disputes in Asia. This paper, based on a review of the case law of UNCLOS tribunals, as well the advantages and limitations of the system, argues that the UNCLOS dispute settlement system can make meaningful contributions to resolving thorny disputes between Asian States. It does so by providing a solution to the dispute brought before them, clarifying the legal framework for the conduct of the parties and facilitating cooperation amongst countries in the region.
\end{abstract}

The 1982 United Nations Convention on the Law of the Sea ("UNCLOS" or "the Convention"), often referred to as the "Constitution for the Oceans", 3 establishes a system for dispute settlement which constitutes an integral part of the Convention. In particular, Part XV of UNCLOS on Settlement of Disputes sets out compulsory dispute settlement procedures which are binding on a State once it becomes a party to the Convention. Even though there are several exclusions and limitations to the compulsory jurisdiction of the UNCLOS dispute settlement

\footnotetext{
${ }^{1}$ PhD Candidate, Faculty of Law, University of Cambridge.

${ }^{2}$ United Nations Convention on the Law of the Sea, Dec. 10, 1982, 1833 U.N.T.S. 396.

3 "A Constitution for the Oceans", Remarks by Ambassador Tommy Koh of Singapore, President of the Third United Nations Conference of the Law, Statements by the President on 6 and 11 December 1982, online: $<\underline{\text { http://www.un.org/depts/los/convention agreements/texts/koh english.pdf }>}$.
} 
bodies, Part XV is considered to have established one of most comprehensive and innovative dispute settlement systems to date. ${ }^{4}$

The majority of States in Asia are parties to UNCLOS. This means that they are entitled to invoke the dispute settlement procedures to settle a dispute concerning UNCLOS. Yet thus far, the UNCLOS dispute settlement system has only been utilized in a handful of instances by Asian States to resolve their maritime disputes. This reality may reflect the general reluctance, perhaps even skepticism, on the part of many Asian States towards third-party mechanisms in the resolution of their disputes, especially those considered highly politically sensitive in nature. ${ }^{5}$ However, based on a review of the disputes between Asian States handled by UNCLOS dispute settlement bodies, this paper argues that the UNCLOS dispute settlement system has great potential and may play a meaningful role in the resolution of long-standing territorial and maritime disputes in Asia.

To that end, the paper will first look at the decisions taken by the International Tribunal for the Law of the Sea ("ITLOS") and Annex VII arbitral tribunals in four maritime disputes between Asian countries brought before them, all of which touch upon legal issues that are at the heart of many of the existing maritime disputes in Asia. Based on the results of these cases, the paper will proceed to analyze the contributions of UNCLOS tribunals to the resolution of the disputes in question and to the maintenance of peace in the region. The paper then examines the advantages and limitations of the UNCLOS dispute settlement in resolving maritime disputes in Asia, before reaching the conclusion regarding the role that the UNCLOS dispute settlement system may play in the peaceful resolution of maritime disputes in the region.

\section{MARITIME DISPUTES BETWEEN ASIAN STATES BEFORE UNCLOS DISPUTE SETTLEMENT BODIES}

To date, UNCLOS dispute settlement bodies have received four cases in which both the applicants and the respondents are States from Asia. These cases will be the focus of this Section. It should be noted that even though the International Court of Justice ("ICJ") is listed under Article 287 as one of the fora to which UNCLOS State parties can bring their disputes; thus far, none of the cases brought before the ICJ have been initiated under the auspices of

\footnotetext{
${ }^{4}$ John E. NOYES, "Compulsory Third-Party Adjudication and the 1982 United Nations Convention on the Law of the Sea" (1989) 4 CJIL 675; O.A. ADEDE, "Settlement of Disputes Arising Under the Law of the Sea Convention" (1975) 69 AJIL 798.

${ }^{5}$ Tara DAVENPORT, "Joint Development in Asia: Lessons for sustainable peace in the South China Sea” 8th Asian Law Institute Conference, Japan 2011; Park Hee WON, The Law of the Sea and Northeast Asia: A Challenge for Cooperation (Kluwer Law International, 2000) 117.
} 
UNCLOS. Therefore, even though there have been maritime cases brought before the ICJ involving two Asian States, ${ }^{6}$ they are beyond the purview of this article.

\section{A. Land Reclamation in and around the Straits of Johor (Malaysia v. Singapore)}

On 4 July 2003, Malaysia instituted arbitral proceedings under Annex VII UNCLOS arbitral tribunal in a dispute concerning land reclamation by Singapore in and around the Straits of Johor. Malaysia opposed these activities on grounds of transboundary environmental impact and potential implications on its side of the waters. Pending the constitution of the arbitral tribunal, Malaysia requested ITLOS to prescribe provisional measures pursuant to Article 290(5) UNCLOS. Malaysia asked ITLOS to order Singapore to suspend its land reclamation activities and to cooperate with Malaysia, including providing Malaysia with full information when conducting the activities, ${ }^{7}$

Under Article 290(5), provisional measures may only be prescribed "if the urgency of the situation so requires" to preserve the rights of the parties or to protect the marine environment. In the sector of Tuas, the ITLOS held that the evidence showed no urgency and the rights that Malaysia claimed in the territorial sea faced no risk of being irreversibly damaged. The Tribunal, therefore, declined to prescribe any provisional measure in this sector. ${ }^{8}$ In the area of Pulau Tekong, the Tribunal held that Singapore had not undertaken any assessment on the impact of the land reclamation on the waters under the jurisdiction of Malaysia. Consequently, it could not exclude the adverse effects that land reclamation works may have on the marine environment. ${ }^{9}$ ITLOS, however, did not order the suspension of the land reclamation works as requested by Malaysia. Instead, it ordered the establishment of a group of independent experts with the mandate to conduct a study on the effects of Singapore's land reclamation and to propose measures to deal with any adverse effects of such land reclamation. ${ }^{10}$

Subsequently, the parties notified both ITLOS and the Annex VII arbitral tribunal that the Group of Experts established pursuant to the ITLOS Order had completed its report, ${ }^{11}$ on the

\footnotetext{
${ }^{6}$ Sovereignty over Pulau Ligitan and Pulau Sipadan (Indonesia/Malaysia), [2002] I.C.J. Rep. 625; Sovereignty over Pedra Branca/Pulau Batu Puteh, Middle Rocks and South Ledge (Malaysia/Singapore), [2008] I.C.J. Rep. 12.

${ }^{7}$ Land Reclamation in and around the Straits of Johor (Malaysia v. Singapore), Provisional Measures, Order of 8 October 2003, [2003] ITLOS Rep. 10.

${ }^{8}$ Ibid., at 72 .

${ }^{9}$ Ibid., at 96.

${ }^{10}$ Ibid., at 96.

${ }^{11}$ Case Concerning Land Reclamation by Singapore in and Around the Straits of Johor (Malaysia v. Singapore), Decision of 1 September 2005, [2007] XXVII Reports of International Arbitral Awards 133 at 19.
} 
basis of which, they signed a Settlement Agreement in May 2005. ${ }^{12}$ The parties then requested the arbitral tribunal to deliver an Award binding upon the Parties in accordance with the terms set out in the Settlement Agreement. ${ }^{13}$ What this essentially meant was that even though a third party was asked to render a binding decision, the content of that decision had already been determined by the two parties themselves. The arbitral proceedings that would have otherwise taken place were therefore terminated.

This was not the first land reclamation activity carried out by Singapore, and certainly not the first one to have met objection from Malaysia. ${ }^{14}$ Given the lack of environmental impact assessment, and as the Tribunal admitted, the possibility of adverse impact on the marine environment in the Strait of Johor, one could reasonably have expected ITLOS to order the suspension of land reclamation activities as requested by Malaysia. However, given its geographical condition, Singapore conducts land reclamation activities on a frequent basis in order to provide additional space to accommodate its housing, industrial and economic needs. ${ }^{15}$ In a relatively small area with a sensitive ecological system such as that of the Strait of Johor, ${ }^{16}$ the impacts of land reclamation activities may not be limited to the waters under the jurisdiction of Singapore. The prevalence of land reclamation activities in region means that the suspension of one project may not be of much use, both to addressing the conflict between the parties and to the preservation of the marine environment. It was thus important that ITLOS placed utmost emphasis on the need for cooperation between the parties. By stressing the duty to cooperate and by prescribing concrete measures to ensure that the duty to cooperate would be observed, ITLOS was able to not only settle the dispute before it, but also provide authoritative guidance for future cases in which the same issues might arise.

Furthermore, the establishment of a Group of Expert allowed the parties to fulfill their international obligation, i.e the duty to cooperate, and at the same time, retain a final say as to the measures to be adopted. Some States fear that by going to international courts and tribunals, the final solution will be one that is imposed by a third party which could be at odds with their own national interests. The ITLOS Order and the subsequent events prove that this is not always the

\footnotetext{
12 Ibid., at 21.

${ }^{13}$ Ibid., at 24.

${ }^{14}$ KOG Yue-Choong, Environmental Management and Conflict in Southeast Asia - Land Reclamation and its Political Impact, Institute of Defence and Strategic Studies Singapore Working Paper Series, online: $<$ https://www.rsis.edu.sg/wp-content/uploads/rsis-pubs/WP101.pdf $>$.

15 Tommy KOH, Jolene LIN, "The Land Reclamation Case: Thoughts and Reflections" (2006) 10 Singapore Yearbook of International Law 1 at 1.
}

${ }^{16}$ KOG Yue-Choong, supra note 14. 
case. The Order, as mentioned, allowed the parties to reach an agreement in their own terms regarding a variety of issues which are not only limited to land reclamation. ${ }^{17}$ In other words, it paved the way for more comprehensive cooperation, even beyond the scope of its provisional measures.

One may wonder what the use of third-party settlement in this case was, given that the parties had already managed to reach an agreement for a final solution of their own accord. The answer lies in the fact that third party mechanism is useful to help break the initial impasse and to provide an alternative option for the parties to resolve their disputes. In fact, it is not uncommon for neighbouring States to conflict with each other in more than one issue. For countries with a history of rivalry, such as Malaysia and Singapore, the parties tend to politicize the dispute to the extent that it would be difficult to step back or compromise without third party intervention. ${ }^{18}$ In fact, Tommy Koh observed that the outcome of the Land Reclamation case helped increase Singapore's confidence in third-party dispute settlement. ${ }^{19}$ The ITLOS Order, therefore, set a favourable precedence for the use of international judicial mechanism for the countries in the region.

Apart from resolving the dispute between the parties, ITLOS has also been praised in the Land Reclamation case for ensuring that the environment was protected by reference to independent, expert advice. One scholar commented that compared with prior cases in which the issue of marine environment protection also arose, such as the Southern Bluefin Tuna and MOX Plant cases, ${ }^{20}$ ITLOS in this case showed greater willingness to become involved in the detailed modalities of environmental dispute resolution through a high degree of supervision of settlement process. $^{21}$

\section{B. Bangladesh/Myanmar}

The maritime boundary dispute between Bangladesh and Myanmar had for a long time been a bone of contention in the two States' bilateral relationship. Efforts to settle the disputes had taken

\footnotetext{
${ }^{17}$ See Annex of Land Reclamation Award, supra note 11.

${ }^{18}$ Tommy KOH, Jolene LIN, supra note 15 at 6.

${ }^{19}$ Ibid.

${ }^{20}$ Southern Bluefin Tuna (New Zealand v. Japan; Australia v. Japan), Provisional Measures, Order of 27 August 1999, [1999] ITLOS Rep. 280; MOX Plant (Ireland v. United Kingdom), Provisional Measures, Order of 3 December 2001, [2001] ITLOS Rep. 95.

${ }^{21}$ Tim STEPHENS, International Courts and Environment Protection (Cambridge: Cambridge University Press, 2009) 242.
} 
place for decades with limited progress. ${ }^{22}$ In 2009, Bangladesh decided to utilize the UNCLOS dispute settlement mechanism and the dispute between the two was brought to ITLOS, ${ }^{23}$ even though initially Bangladesh instituted proceedings before Annex VII arbitral tribunal. In their submissions, the parties requested ITLOS to draw boundary lines to delimit their territorial sea, exclusive economic zone ("EEZ") and continental shelf.

As per the parties' request, first ITLOS applied the equidistance principle as stipulated under Article 15 UNCLOS to delimit the territorial sea. In the course of doing so, the Tribunal gave St. Martin's Island, which belongs to Bangladesh, a 12 nautical mile (nm) territorial sea. ${ }^{24}$ For the EEZ and continental shelf, ITLOS decided to draw a single boundary for both maritime zones by following the three-stage delimitation process which was laid out by the ICJ in the Black Sea case. ${ }^{25}$ As the first step, ITLOS rejected Bangladesh's argument that the angle-bisector line should be employed instead of the equidistance line. ${ }^{26}$ The Tribunal also rejected Bangladesh's submissions that St. Martin's Island and the Bengal depositional system should be taken into account as relevant circumstances. ${ }^{27}$ It only accepted Bangladesh's argument concerning the concavity of its coastline. ${ }^{28}$ Accordingly, the Tribunal adjusted the provisional line, with a view to avoid the equidistance line cutting off the southward projection of the coast of Bangladesh as a result of its concavity. Finally, applying the proportionality test, the Tribunal was satisfied that the end result was proportionate, which meant that the use of the adjusted equidistance line produced an equitable result for both States. $^{29}$

Perhaps the most noticeable aspect of ITLOS' judgment in the Bangladesh/Myanmar case was the delimitation of the continental shelf beyond $200 \mathrm{~nm}$, usually referred to as the outer continental shelf. Article 76(8) UNCLOS requires States, when claiming a continental shelf beyond $200 \mathrm{~nm}$, to make a submission to specify the limits of its continental shelf to a technical

\footnotetext{
${ }^{22}$ See Jared BISSINGER, "The Maritime Boundary Dispute between Bangladesh and Myanmar: Motivations, Potential Solutions, and Implications" (2010) 19 Asia Policy 103.

${ }^{23}$ Delimitation of the Maritime Boundary in the Bay Of Bengal (Bangladesh/Myanmar), Judgment, [2002] ITLOS Rep. 4 at 3, 4.

${ }^{24}$ Ibid., at $152-53$.

${ }^{25}$ Ibid., at 233. This three-stage process involves: (i) drawing a provisional equidistance line, (ii) determining whether there are any relevant circumstances that call for the adjustment of the provisional equidistance line and (iii) using the proportionality test to ensure that the final outcome is equitable.

${ }^{26}$ Ibid., at $234-39$.

${ }^{27}$ Ibid., at 318,320 .

${ }^{28}$ Ibid., at 324 .

${ }^{29}$ Ibid., at 477 .
} 
body called the Commission on the Limits of the Continental Shelf ("CLCS" or "the Commission"). Once the CLCS has made a recommendation with regards to a State's submission, the outer limits of the continental shelf established based on this recommendation will be final and binding. In this case, both Bangladesh and Myanmar had made their submissions to the CLCS prior to the initiation of the case; however, Bangladesh objected to the CLCS considering Myanmar's submission. As the CLCS is barred from examining any submission relating to a disputed area unless all parties to such a dispute give their consent, ${ }^{30}$ the Commission did not issue any recommendation for either party. ${ }^{31}$ Despite the absence of the CLCS' recommendation as to where the limits of the continental shelves would be beyond 200nm, ITLOS was satisfied that the thickness of the sediment in the Bay of Bengal enabled both parties to claim an outer continental shelf in accordance with Article 76 (4)(a)(i), and that the parties' continental shelves overlapped.${ }^{32}$ On that basis, it found that it had jurisdiction and exercised that jurisdiction to delimit the extended continental shelf. ${ }^{33}$ The Tribunal then extended the boundary line used within the $200 \mathrm{~nm}$ maritime area to that beyond $200 \mathrm{~nm} .^{34}$

The delimitation of the outer continental shelf created for the first time in international jurisprudence a so-called "grey area" which is an area located beyond 200nm from the coast of Bangladesh but within 200nm from the coast of Myanmar, yet on Bangladesh side of the delimitation line. ${ }^{35}$ In this area, the sovereign rights with respect to the seabed and subsoil belong to Bangladesh, while those with respect to the superjacent water rest with Myanmar.

The dispute between Bangladesh and Myanmar was the first maritime boundary case dealt with by ITLOS. The outcome of the case, therefore, carried great significance not only for the parties concerned but also for the reputation of the Tribunal as a specialized court for law of the sea.

First, the judgment put to rest a decade-old dispute between two neighbouring countries, which helped to deflect any potential military clashes and ensure political stability for the two

\footnotetext{
${ }^{30}$ Rules of the Procedure of the Commission on the Limits of the Continental Shelf, Annex I, paragraph 5(a).

${ }^{31}$ Bangladesh/Myanmar, supra note 23 at 389-90.

${ }^{32}$ Bangladesh/Myanmar, supra note 23 at 444-46.

${ }^{33}$ This was not the first time an international tribunal established that it had jurisdiction to delimit the outer continental shelf. But it was the first time the tribunal exercised its jurisdiction to do so. See Arbitration between
} Barbados and the Republic of Trinidad and Tobago, relating to the delimitation of the exclusive economic zone and the continental shelf between them, Decision of 11 April 2006, [2006] XXVII Reports of International Arbitral Awards 147 at 209.

${ }^{34}$ Ibid., at 462.

35 Ibid., at 463 . 
countries, as well as for the Bay of Bengal area. The boundary dispute between Bangladesh and Myanmar, despite having existed since the former's independence, was only seriously rekindled following the commencement of natural gas exploration by Myanmar in waters claimed by Bangladesh. ${ }^{36}$ The prospects of exploitable resources and increasing internal demands prompted each State to deploy naval forces to prevent efforts from the other to conduct survey or exploration in the waters that each claimed to be under its jurisdiction. At one point, this tension escalated to a serious standoff in the Bay of Bengal, heightening the risk of war between two otherwise friendly Asian nations. ${ }^{37}$ Against this bleak background and in light of the fact that neither country preferred joint development, the judgment provided a peaceful and workable solution to the conflict between the two States. ${ }^{38}$

Second, the judgment opened up important prospects for the two countries to boost their economic development through exploitation of the resources in their delimited maritime zones-including fisheries, mineral resources, natural gas-without fear of interruption or objection. In other words, the ITLOS judgment helped put an end to a dispute that had impeded economic development for the two countries which are among the least developed members of the international community. ${ }^{39}$

The fact that ITLOS proceeded to delimit the continental shelf beyond $200 \mathrm{~nm}$ is also noteworthy. ${ }^{40}$ The situation that often arises with regards to delimitation of outer continental shelf is that a court cannot delimit overlapping extended continental shelves unless the States in question have established that they have entitlements to the continental shelf beyond $200 \mathrm{~nm}$. This, in turn, can only be done upon the recommendation of the CLCS. However, as was in this case, the CLCS cannot render recommendations for submissions which are disputed by other parties. This ultimately results in an impasse before both the CLCS and the court, which in effect freezes any efforts the resolution process. The decision of ITLOS to delimit the outer continental

${ }^{36}$ Sarah WATSON, “The Bangladesh/Myanmar Maritime Dispute: Lessons for Peaceful Resolution” Asia Maritime Transparency Initiative (19 October 2015), online: <http://amti.csis.org/the-bangladeshmyanmar-maritime-disputelessons-for-peaceful-resolution/>.

37 Animesh ROUL, "Standoff in the Bay of Bengal" The International Relations and Security Network (20 November 2008), online: <http://www.isn.ethz.ch/Digital-Library/Articles/Detail/?lang=en\&id=93998>.

38 Jared BISSINGER, supra note 22 at 137.

${ }^{39}$ Pranab Kumar PANDAY, "Bangladesh and Myanmar Resolve Longstanding Maritime Dispute” East Asia Forum (26 April 2012), online:

< $\underline{\text { http://www.eastasiaforum.org/2012/04/26/bangladesh-and-myanmar-resolve-longstanding-maritime-dispute/> }}$.

40 Robin CHURCHILL, "The Bangladesh/Myanmar Case: Continuity and Novelty in the Law of Maritime Boundary Delimitation” (2012) 1(1) Cambridge Journal of International and Comparative Law 137. 
notwithstanding the absence of a recommendation from the CLCS helped to resolve what Bangladesh called "a jurisdictional black hole" ${ }^{41}$ and allowed the settlement of a long-standing dispute to move forward.

Some scholars have expressed concerns that in calling for cooperation in the "grey area", ITLOS might have been overly-optimistic. ${ }^{42}$ After all, the parties were unable to resolve their differences after many years of diplomatic effort. Notwithstanding the final and binding ITLOS judgment, they may have to return to the negotiating table to agree on the allocation of jurisdiction in the "grey area". Indeed, the creation of a zone of multiple jurisdiction may pose functional difficulties for the parties in exercising their sovereign rights and jurisdiction. Nevertheless, to date, few reports have emerged regarding on the parties' conflicts in this "grey area". In practice, cooperation is not impossible as several States have managed to agree on a cooperation scheme in areas of the same nature. ${ }^{43}$

\section{Bangladesh/India}

The maritime boundary dispute between Bangladesh and India concerned the remaining part of the Bay of Bengal, the north-western part. The two States had been engaged in inconclusive negotiations on the delimitation of their maritime boundary since the 1970s and the disputes became acute as a consequence of the prospects of and the States' internal demands for gas in the overlapping area. ${ }^{44}$ Bangladesh initiated proceedings before Annex VII arbitral tribunals against both Myanmar and India in 2009. As mentioned, Myanmar subsequently proposed to transfer the case to ITLOS, to which Bangladesh agreed, while the case between Bangladesh and India continued through arbitration. The Arbitral Award was rendered in July $2014 .^{45}$

The submissions that Bangladesh brought before the arbitral tribunal were very much similar to those in the case with Myanmar before ITLOS. Bangladesh requested the tribunal to delimit

\footnotetext{
${ }^{41}$ Bangladesh/Myanmar, supra note 23 at 358.

${ }^{42}$ Clive SCHOFIELD, Anastasia TELESETSKY, 'Grey Clouds or Clearer Skies Ahead? Implications of The Bay of Bengal Case' (2012) 3 Law of the Sea Reports at 10.

${ }^{43}$ See David A. COLSON, "The Delimitation of the Outer Continental Shelf Between Neighboring States" (2003) 97 American Journal of International Law 91 at 94; Raghavendra MISHRA, "The 'Grey Area' in the Northern Bay of Bengal: A Note on a Functional Cooperative Solution” (2016) 47(1) Ocean Development \& International Law 29. ${ }^{44}$ Naomi BURKE, “Annex VII Arbitral Tribunal Delimits Maritime Boundary Between Bangladesh and India in the Bay of Bengal' (2014) 18 ASIL Insights, online: < $\underline{\text { http://asil.org/insights/volume/18/issue/20/annex-vii-arbitral- }}$ tribunal-delimits-maritime-boundary-between\# edn3>.

45 Bay of Bengal Maritime Boundary Arbitration (Bangladesh/India), Arbitral Award at 411, online: $<$ http://www.pca-cpa.org/showpage5a3b.html?pag id=1376>.
} 
the overlapping territorial seas, EEZs and continental shelves with India. It should be noted also that three out of the five arbitrators in the Bangladesh/India case were judges of ITLOS who also dealt with the Bangladesh/Myanmar case. Coupled with the fact that the areas delimited shared many geographical similarities, it is perhaps not difficult to understand why the Arbitral Award as well as the parties' arguments was extensively based on the ITLOS judgment. In delimiting the territorial sea, the arbitral tribunal applied the equidistance/median line in accordance with Article 15 after rejecting Bangladesh's argument that "special circumstances" called for the use of another method. ${ }^{46}$ The arbitral tribunal only adjusted the equidistance line so that the eventual boundary starts from land boundary terminus and run southwards until it meets the median line. ${ }^{47}$

For the delimitation of the EEZ and continental shelf, the arbitral tribunal continued to follow the three-stage delimitation process. First, the tribunal, having rejected Bangladesh's argument in favour of the use of angle-bisector, drew a provisional equidistance line. ${ }^{48}$ Then the tribunal adjusted the provisional equidistance line to take into account of the cut-off effect produced by the concavity of Bangladesh's coast. In line with concept of the single continental shelf, theadjustment of the provisional line for the EEZ and continental shelf was considered in connection with the continental shelf beyond $200 \mathrm{~nm}^{49}$

The approach of the arbitral tribunal to delimiting the outer continental shelf followed that of ITLOS in the Bangladesh/Myanmar case. The arbitral tribunal held that the provisional equidistance line should still be applied but adjusted to take into account the cut-off effect produced by the concavity of Bangladesh's coast. ${ }^{50}$ As with the ITLOS judgment, such a boundary created a "grey area" which lay beyond 200nm from the coast of Bangladesh and within 200nm from the coast of India, but on Bangladesh's side of the boundary. Endorsing what ITLOS had previously held with regards to the "grey area", the arbitral tribunal concluded that the establishment of "an area in which the States concerned have shared right is not unknown under the Convention", and called on the parties to determine the measures appropriate in a cooperative spirit to exercise their rights and fulfill their duties under UNCLOS. ${ }^{51}$

The Arbitral Award in the Bangladesh/India case, together with the Bangladesh/Myanmar judgment of ITLOS, completed the delimitation of the Bay of Bengal. The resolution of maritime

\footnotetext{
${ }^{46}$ Ibid., at 248 .

${ }^{47}$ Ibid., at 274-76.

${ }^{48}$ Ibid., at 346.

${ }^{49}$ Ibid., at 437.

${ }^{50}$ Ibid., at 408.

${ }^{51}$ Ibid., at 507-08.
} 
delimitation disputes ended decades of uncertainty as to allocation of maritime entitlements, ${ }^{52}$ which created political and economic security and stability for all States concerned. Similar to the Bangladesh/Myanmar judgment, the Award provides clarity and legal certainty as to the exact location of the maritime boundary between the two nations. In light of the discoveries of huge natural gas deposits beneath the sea, proving the Bay of Bengal to be a highly lucrative site of energy reserves, ${ }^{53}$ the decision was important to attract investors to engage in exploration and exploitation of oil and gas. The judgment was broadly accepted by both the countries as a positive development for further consolidation of friendly relations especially given the geostrategic and political significance of greater Indian Ocean region and South Asian subregion. The foreign minister of Bangladesh called it 'a victory for friendship between Bangladesh and India', while a statement from India's external affairs ministry says that the boundary settlement will 'enhance mutual understanding and goodwill between India and Bangladesh by bringing to closure a long-pending issue' ${ }^{54}$

\section{Philippines v. China}

The South China Sea has witnessed serious escalation which has resulted in the use of military forces, arms race and nationalist public demonstrations in several countries. ${ }^{55}$ Meanwhile, the lack of tangible progress in resolving these conflicts has caused serious concerns not only for the countries in the region but also for the international community. In such a context, the decision of the Philippines to initiate proceedings against China before Annex VII arbitral tribunal in January 2013 unsurprisingly attracted considerable attention.

By way of background, the disputes in the South China Sea between China, Malaysia, the Philippines, Vietnam, and to a certain extent, Brunei can be categorized into two main types: (i) disputes concerning the islands and (ii) disputes concerning maritime delimitation. The first type

\footnotetext{
52 Naomi BURKE, supra note 44.

${ }^{53}$ Rajeev SHARMA, "UN tribunal puts an end to 40-year-old India-Bangladesh maritime dispute" RT Question More (16 July 2014), online: <https://www.rt.com/op-edge/172960-un-india-bangladesh-dispute-end/>

${ }^{54}$ Rupak BHATTACHARJEE, “Delimitation of Indo-Bangladesh Maritime Boundary” Institute for Defence Studies and Analyses (19 August 2014), online: < $\underline{\text { http://www.idsa.in/idsacomments/DelimitationofIndo- }}$ Bangladesh rbhattacharjee 190814>.

55 Ankit PANDA, "Reclamation, Arbitration, Competition: South China Sea Situation Report" The Diplomat (09 May 2015), online: < http://thediplomat.com/2015/05/reclamation-arbitration-competition-south-china-sea-situationreport/>; Julian BORGER, Tom PHILLIPS, "How China's artificial islands led to tension in the South China Sea" The Guardian (27 October 2015), online: < http://www.theguardian.com/world/2015/oct/27/tensions-and-territorialclaims-in-the-south-china-sea-the-guardian-briefing $>$.
} 
of disputes relating to islands can be further divided into two smaller subcategories, which are (i) disputes relating to sovereignty over the islands and (ii) disputes relating to the legal status of the features within the groups of islands under Article 121 UNCLOS. $^{56}$ The most controversial claim in the South China Sea perhaps belongs to China with its nine-dash line encompassing almost the whole of the South China Sea. ${ }^{57}$ China has not to date provided any official explanation not clarification of legal basis for this line.

The Philippines' case, however, did not involve all of these issues. The Philippines requested the arbitral tribunal to consider 15 submissions, which could be broadly grouped into three interrelated matters. First, China's claims based on "historic rights" encompassed within its so-called "nine-dash line" were inconsistent with the Convention and therefore invalid. Second, under the Convention, certain maritime features claimed by both China and the Philippines should be properly characterized as rocks or low tide elevations, not islands. Third, China violated the Convention by interfering with the exercise of the Philippines' sovereign rights and freedoms under the Convention and through construction and fishing activities that harmed the marine environment. $^{58}$

China, for its part, officially announced that it would not participate in the arbitral proceedings. Nevertheless, China hardly adopted a hands-off policy towards the arbitral proceedings. ${ }^{59}$ Officially, the Chinese government issued a Position Paper in which China argued that the arbitral tribunal did not have jurisdiction to hear the case for three main reasons: (i) the subject-matter of the arbitration is the territorial sovereignty over maritime features in the South China Sea, (ii) China and the Philippines had agreed to settle their disputes through negotiations through bilateral instruments and the Declaration on the Conduct of the Parties in the South China Sea (DOC) and (iii) even if the subject-matter of the dispute concerned the UNCLOS, it

\footnotetext{
${ }^{56}$ See Robert BECKMAN, "The UN Convention on the Law of the Sea and the Maritime Disputes in the South China Sea" (2013) 107(1) The American Journal of International Law 142.

${ }^{57}$ Note of China No. CML/17/2009 dated 7 May 2009, online:

<http://www.un.org/Depts/los/clcs_new/submissions_files/mysvnm33_09/chn_2009re_mys_vnm_e.pdf >

58 The Republic of the Philippines $v$ The People's Republic of China, Award on Jurisdiction and Admissibility at 46, online: <http://www.pcacases.com/web/sendAttach/1506>

59 Lan NGUYEN, "South China Sea: Philippines v. China" The Diplomat (27 July 2015), online: < $\underline{\text { http://thediplomat.com/2015/07/south-china-sea-philippines-v-china/> }}$.
} 
constituted an integral part of maritime delimitation which is excluded from the jurisdiction of the tribunal by virtue of China's declaration in $2006 .{ }^{60}$

In spite of China's non-appearance, in accordance with Article 9 of Annex VII UNCLOS, the arbitration still moved forward. As the arbitral tribunal treated China's communications as a plea concerning the tribunal's jurisdiction, it bifurcated the proceedings into two stages to consider issues of jurisdiction and merits separately. ${ }^{61}$ This bifurcation provided some indication as to the importance of jurisdictional issues for the case, and from a broader perspective, the difficulties of utilizing third-party settlement for the South China Sea disputes.

The tribunal rendered its Arbitral Award on Jurisdiction and Admissibility in October 2015, in which it decided to uphold jurisdiction for seven submissions, deferred seven submissions for consideration in conjunction with the merits and requested the Philippines to clarify one submission. In so doing, the arbitral tribunal essentially rejected two out the three jurisdictional objections raised by China. In particular, concerning the nature of the dispute, the arbitral tribunal rejected China's characterization of the Philippines' submissions as concerning sovereignty or maritime delimitation. The tribunal held that Philippines had not requested it to rule on sovereignty, nor would the decision on any of the Philippines' submissions require an implicit determination of sovereignty. ${ }^{62}$ The tribunal also held that the Philippines' submissions concerning the insular features' entitlement to maritime zones did not constitute a request for maritime delimitation. The fixing of the extent of the parties' entitlement and the delimitation of maritime boundary are two distinct issues. ${ }^{63}$

The tribunal also found that there was no obstacle to its jurisdiction under Section 1 of Part $\mathrm{XV}$ which lays out the preconditions to the tribunal's jurisdiction. The tribunal found that the instruments documenting the Philippines and China's commitment to dispute settlement, namely bilateral statements, the Declaration on the Conduct of Parties in the South China Sea ("DOC"), the Treaty of Amity and the Convention on Biodiversity could not bar the tribunal's jurisdiction under Article $281,{ }^{64}$ or Article $282 .{ }^{65}$ Finally, with regards to the obligation to exchange views under Article 283, the tribunal found that there was abundant evidence showing that the parties

\footnotetext{
${ }^{60}$ Ministry of Foreign Affairs of the People's Republic of China, Position Paper of the Government of the People's Republic of China on the Matter of Jurisdiction in the South China Sea Arbitration Initiated by the Republic of the Philippines, 7 December 2014, online: < http://www.fmprc.gov.cn/mfa eng/zxxx 662805/t1217147.shtml .

${ }^{61}$ Philippines v. China, supra note 58 at 68.

${ }^{62}$ Ibid., at 153.

${ }^{63}$ Ibid., at 156.

${ }^{64}$ Ibid., at 229, 248, 269, 289

${ }^{65}$ Ibid., at 302, 310, 321
} 
had engaged in serious exchange of views. ${ }^{66}$ Recalling that Article 283 only requires the parties to exchange views regarding the means by which a dispute between them may be settled, and not regarding the subject matter of the dispute, the tribunal was satisfied that the parties had discharged of their obligations under Article $283 .{ }^{67}$

Lastly, the tribunal turned its attention to the limitations and exclusions to compulsory jurisdiction under Articles 297 and 298, including the effect of China's declaration under Article 298 to exclude certain disputes from its compulsory jurisdiction. The tribunal found that the question of whether these articles applied to exclude its jurisdiction was significantly interwoven with the merits. Therefore, the tribunal deferred a decision on the jurisdiction those submissions of the Philippines that may or may not be excluded from the tribunal's jurisdiction by virtue of Articles 297 and 298 to the merits phase. ${ }^{68}$

In the Award on Merits rendered in July 2016, the tribunal confirmed jurisdiction for all the remaining submissions, except two. ${ }^{69}$ The tribunal confirmed that neither the exception of historic rights under Article 298(1)(a)(i) nor the exception of law enforcement under Article 298(1)(b) applied to exclude the tribunal's jurisdiction. ${ }^{70}$ The only exception that was applicable was that concerning military activities, which excluded the tribunal from exercising its jurisdiction over Submission 14(a) to (c). ${ }^{71}$

On the merits, the tribunal made findings which essentially upheld the majority of the Philippines' submissions. Most notably, the tribunal found that China's claim to the nine-dash line over the South China Sea on the basis of historic rights, or other sovereign rights of jurisdiction "are contrary to the Convention and without lawful effect". 72 Equally important, the tribunal agreed with the Philippines that none of the features mentioned in the Philippines' submissions qualified as islands within the meaning of Article 121(1) UNCLOS, but were instead only rocks within meaning of Article 121(3) or low tide elevations. ${ }^{73}$ The tribunal even went further to hold that none of the features in the Spratlys could be considered islands, and the

\footnotetext{
66 Ibid., at 334-42

${ }^{67}$ Ibid., at 333 .

${ }^{68}$ Ibid., at 396.

69 The Republic of the Philippines $v$ The People's Republic of China, Award (12 July 2016), online: <http://www.pcacases.com/pcadocs/PH-CN\%20-\%2020160712\%20-\%20Award.pdf>

${ }^{70}$ Ibid., at 229, 695 .

${ }^{71}$ Ibid., at 1162 .

${ }^{72}$ Ibid., at. 278

${ }^{73}$ Ibid., at 643-47.
} 
high-tide features could only qualify as "rocks". ${ }^{74}$ This practically means that no littoral State surrounding the South China Sea will be entitled to claim a maritime zone exceeding $12 \mathrm{~nm}$ from these features. The tribunal also found that China breached a series of other obligations under UNCLOS, including the obligation to preserve and protect the marine environment through harmful fishing practices and harmful construction activities, ${ }^{75}$ the obligation to respect the Philippines' sovereign rights over living resources of its EEZ with its activities in the South China Sea, ${ }^{76}$ and the obligation to exercise duties of the flag State over its law enforcement vessels. $^{77}$

The two awards of the Philippines $v$ China arbitration will have a significant impact on the South China Sea disputes, widely considered one of the most complicated maritime disputes in the world. The fact that the non-appearance of China did not impede the arbitral proceedings reaffirmed the compulsory nature of the dispute settlement. The Award on Jurisdiction helped strike down many of the arguments commonly used by China to avoid settling the disputes through third-party procedures. For example, China places great emphasis on bilateral negotiations and insists that this the sole avenue to resolving disputes with its neighbours. ${ }^{78}$ The arbitral tribunal, while acknowledging the importance of negotiations, clarified that States are free to utilize other methods of dispute settlement so long as they are in accordance with international law. ${ }^{79}$

Furthermore, the fact that some of the most controversial issues in the South China Sea were examined in the merits phase contributes to untangling existing legal ambiguities in the South China Sea ${ }^{80}$ For example, although all claimant States acknowledge the need to delimit their overlapping maritime zones, the maritime area subject to delimitation has yet to be identified.

\footnotetext{
${ }^{74}$ Ibid., at 646.

${ }^{75}$ Ibid., at 992-93.

${ }^{76} \mathrm{Ibid}$., at $716,757,814$.

${ }^{77}$ Ibid., at 1109 .

${ }^{78}$ See Jerome A. COHEN, "International Arbitration and Adjudication as South China Sea Confidence-Building Measures" in Murray HIEBERT, Phuong NGUYEN, Gregory B. POLING, eds, Perspectives on the South China Sea: Diplomatic, Legal, and Security Dimensions of the Dispute (Rowman \& Littlefield, 2014); Huy DUONG, "Negotiating the South China Sea" The Diplomat (20 July 2011), online: $<$ http://thediplomat.com/2011/07/negotiating-the-south-china-sea/>.

${ }^{79}$ Philippines $v$. China, supra note 58 at 126.

${ }^{80}$ Jay BATONGBACAL, "Implications of the Philippines v. China Award on Jurisdiction" Asia Maritime Transparency Initiative (5 November 2015), online: $<\underline{\text { http://amti.csis.org/implications-of-the-philippines-v-china- }}$ award-on-jurisdiction/>.
} 
This, in turn, is caused by the lack of agreement among the claimant States as to which areas could be considered "disputed waters" or which are "non-disputed waters". 81 There are two main reasons behind the existence of such obscurity, namely (i) the existence of expansive claims which are not recognized by any other claimants, such as China's nine-dash line and (ii) the claimants' differences in the maritime entitlement of the insular features. It is noteworthy that the arbitral tribunal in its Award on Jurisdiction stated that "the Tribunal is obliged not to permit an overly technical evaluation of the Parties' communications or deliberate ambiguity in a Party's expression of its position to frustrate the resolution of a genuine dispute through arbitration." 82 Indeed, in the merits phase, the tribunal addressed both of the issues of nine-dash line and of maritime entitlement in full. The combined result of the tribunal's finding that maritime claims based on the nine-dash line were contrary to UNCLOS and that none of the features in the Spratlys were entitled to a 200nm maritime zone helped identify the maximum reach of the maritime zones that States could legitimately claim under UNCLOS. As a result, the Award on the Merits significantly reduces areas subject to dispute and provides a basis for States to start substantially addressing the remaining issues before them.

The Award on Merits also has the potential to defuse the tension over territorial sovereignty disputes, even though these fall outside the scope of the arbitral tribunal's jurisdiction. Sovereignty claims over the tiny insular features are usually aimed not at gaining control over the landmass of the features but at the vast maritime zones that are generated from these features up to or, in some cases, beyond 200nm. Such control over the waters translates to possession of exclusive rights to explore and exploit fisheries resources and oil and gas reserves. ${ }^{83}$ This is, however, only possible if these insular features meet the criteria to be considered as islands under Article 121(1) UNCLOS. The holding of the tribunal that all of the features in the Spratlys are merely either rocks under Article 121(3) or low-tide elevations under Article 13 means that they are not entitled to any waters beyond $12 \mathrm{~nm}$. Moreover, for those that qualify as low-tide elevations, they cannot be appropriated unless it is located in the territorial sea of a coastal

\footnotetext{
${ }^{81}$ See, e.g., Socialist Republic of Vietnam, Statement of Foreign Ministry Spokesperson Nguyen Phuong Nga (9 June 2011), online: < http://www.mofa.gov.vn/en/tt baochi/pbnfn/ns110610100618\#kyKoH1NekSr9>.

${ }^{82}$ Philippines $v$. China, supra note 58 at 16.

${ }^{83}$ Tara DAVENPORT, supra note 5; A.O. ELFERINK, "The Islands in the South China Sea: How Does Their Presence Limit the Extent of the High Seas and the Area and the Maritime Zones of the Mainland Coasts?' (2001) 32 Ocean Development and International Law 169.
} 
State. ${ }^{84}$ Such a ruling may put an end to the legitimacy of some sovereignty claims, or at least the reduce desire to exert and enforce sovereignty claims in the South China Sea.

\section{SOME REMARKS ON THE CONTRIBUTIONS OF UNCLOS DISPUTE SETTLEMENT BODIES TO RESOLVING MARITIME DISPUTES IN ASIA}

An examination of the maritime disputes between Asian States which have been brought before ITLOS and Annex VII arbitral tribunals shows that UNCLOS tribunals have made important and meaningful contributions to both the resolution of these specific disputes and beyond.

ITLOS and Annex VII arbitral tribunals managed to provide legal solutions to help the disputing parties resolve their differences. In the Land Reclamation case, although the final resolution was the product of mutual agreement of the two parties, this agreement could not have been possible without the findings of the Group of Expert, whose establishment was required as a provisional measure by ITLOS. The boundaries in the Bay of Bengal established by the ITLOS and Annex VII arbitral tribunal ended the boundary dispute which had loomed over the bilateral relationships of the States concerned for decades. The Award on Jurisdiction in the Philippines $v$. China resolved questions relating to the means of dispute settlement applicable to the case; while the Award on the Merits provided answers to some key points of contention between the two countries in the South China Sea.

The settlement of these disputes had broader bearings. First, in all of these cases, the decisions of UNCLOS tribunals served as the legal foundation for the parties to reject unlawful claims and proceed with their legitimate activities. In the Bay of Bengal cases, the decisions of ITLOS and Annex VII arbitral tribunals established maritime boundaries after years of unsuccessful negotiations, which allowed the States concerned to embark on-or continue with-various economic activities crucial to their economic development. The Annex VII arbitral tribunal in the Bangladesh/India indeed took cognizance of this important function of the decision, stating that "the maritime boundaries between them, must be determined with precision to allow for development and investment." ${ }^{, 85}$ In South China Sea, the Award on Merits, for the first time in international jurisprudence, provided clarification to the meaning of historic rights claims and clarified the regime of islands under Article 121. The Award thus lent an authoritative tool for not only the Philippines but also other States in the region to apply UNCLOS correctly to determine the legitimacy of their own and others' claims and activities.

Second, UNCLOS tribunals laid the foundation for further negotiations and facilitated cooperation and mutual agreements between the parties. The decisions of UNCLOS tribunals,

\footnotetext{
${ }^{84}$ Territorial and Maritime Dispute (Nicaragua v. Colombia) [2012] I.C.J Rep 624 at 26; Philippines v China, supra note 69 , at 309 .

${ }^{85}$ Bangladesh/India, supra note 45, at 218.
} 
despite coming from a third-party, still placed great emphasis on cooperation for the parties to see through to the end of the dispute. ITLOS Order in the Land Reclamation case, for example, struck a balance between reinforcing the binding nature of the duty to cooperate and leaving a margin of appreciation to the parties as to the means to discharge their obligation. As such, this decision helped prevent the duty to cooperate from becoming merely rhetoric. The Bay of Bengal cases created a "grey area" in which the parties concerned were required to exercise their respective sovereign rights in accordance with UNCLOS. They were, nevertheless, free to determine the manner in which such sovereign rights were to be allocated and exercised. Morever, even before a decision was handed down, the mere fact that legal proceedings were underway provided a catalyst for the parties to cooperate more meaningfully. After the initiation of the Bangladesh/Myanmar case to ITLOS, for example, the two parties continued to conduct bilateral negotiations to reach an agreement. ${ }^{86}$ The South China Sea arbitral awards admittedly did not resolve territorial sovereignty and maritime delimitation disputes due to the limits of the tribunals' jurisdiction. However, contrary to what China has insisted, this did not render the arbitration "null and void". ${ }^{87}$ As analyzed, the arbitral awards clarified existing ambiguities, rejected excessive claims, thereby reducing the maritime areas subject to dispute. In other words, the arbitration identified the precise scope of what has always been referred to collectively and vaguely as the "South China Sea disputes". Minor as this may seem, the awards laid a highly important stepping stone for the parties concerned to engage in more substantial negotiations to address the remaining issues that divide them. ${ }^{88}$

Third, and perhaps in consequence of the two above-mentioned contributions, the decisions of UNCLOS tribunals helped avert serious escalation of conflict, possibly military conflict, between the parties. For instance, due to maritime boundary disputes, the Bay of Bengal had to witness several instances of military standoff and clashes both on land and at sea. The establishment of boundary disputes put an end to possibilities of future clashes and ensured a peaceful atmosphere for the region. In the South China Sea case, it may be too early at this point to conclude that the arbitral awards have managed to completely prevent future conflicts in the region. China's initial response to the arbitral awards, i.e rejecting the awards and denouncing

\footnotetext{
${ }^{86}$ Jared BISSINGER, supra note 22, at 110.

${ }^{87}$ Statement of the Ministry of Foreign Affairs of the People's Republic of China on the Award of 12 July 2016 of the Arbitral Tribunal in the South China Sea Arbitration Established at the Request of the Republic of the Philippines, online: < $\underline{\text { http://news.xinhuanet.com/english/2016-07/12/c 135507744.htm> }}$

${ }^{88}$ Chris LARANO, “Philippines' Duterte Says Arbitration Ruling to Be Basis of South China Sea Talks”, The Wall Street Journal (2 September 2016), online: < http://www.wsj.com/articles/philippines-duterte-says-arbitrationruling-to-be-basis-of-south-china-sea-talks-1472822919>
} 
the arbitral tribunal, has prompted doubts regarding the extent to which the arbitration could have an impact on China's behaviour and the usefulness of the Philippines' resort to the UNCLOS dispute settlement system. China's non-compliance rhetoric, however, may not be determinative of its long-term reaction. As will be analyzed below, although international law does not contain an enforcement mechanism comparable to those of domestic legal systems, in the majority of cases, States do eventually comply with the decisions of international courts and tribunals.

Finally, the UNCLOS case law highlights the importance of adjudication and arbitration in resolving highly politically, sensitive disputes. It serves a sound reminder that under international law, all States are equal sovereigns and are regulated by the rule of law. ${ }^{89}$ Even though recent decades has witnessed an increasing number of Asian States willing to settle disputes between them through international legal binding adjudication, these are mostly for economic-related disputes. ${ }^{90}$ Moreover, most of them are between States which are at relatively the same level of development and there was mutual agreement between the parties to seek a third-party decision. In such context, the fact that the Philippines brought China to arbitration-amidst the latter's rejection-seems to have departed from the trend. This was a highly laudable move, which may inspire similar response from neighbouring countries. More recently, other States in the region such as Vietnam and Indonesia have indicated that they do not rule out the possibility of taking China to an international court and tribunal. ${ }^{91}$ In this sense, the UNCLOS dispute settlement system provides a unique avenue for small States to compel adherence to the rule of law.

\section{WHAT ROLE CAN THE UNCLOS DISPUTE SETTLEMENT SYSTEM PLAY IN RESOLVING MARITIME DISPUTES IN ASIA?}

\footnotetext{
${ }^{89}$ Bernard H OXMAN, "Courts and Tribunals: ICJ, ITLOS and Arbitral Tribunals" in Donald R. ROTHWELL, A.O. ELFERINK, Karen N. SCOTT, Tim STEPHENS, eds., Oxford Handbook of the Law of the Sea (Oxford: Oxford University Press 2015), 394.

${ }^{90}$ Leonardo BERNARD, Michael EWING-CHOW, "A Rising Tide: Law of the Sea Disputes in Asia and Arbitration" (2014) July Asian Dispute Review.

${ }^{91}$ Rosemarie FRANCISCO, Manuel MOGATO, "Vietnam PM says considering legal action against China over disputed waters" Reuters (22 May 2014), online: < $\underline{\text { http://www.reuters.com/article/us-vietnam-china- }}$ idUSBREA4K1AK20140522>; Kristine KWOK, “China wants to avoid court over maritime disputes, says Vietnam official" South China Morning Post $\quad$ (2 June 2014$)$,

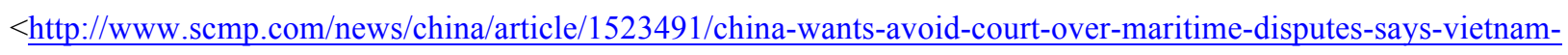
official>; Randy FABI, "Indonesia says could also take China to court over South China Sea" Reuters (11 November 2015), online: < http://www.reuters.com/article/us-southchinasea-china-indonesiaidUSKCN0T00VC20151111>.
} 


\section{A. The Advantages of the UNCLOS Dispute Settlement System}

Having examined the contributions made by ITLOS and Annex VII arbitral tribunals, the question that arises is whether these contributions could only have been made exclusively by UNCLOS bodies. In other words, if the parties had reached an agreement to bring the cases to any different dispute settlement body, could such body not have been able to resolve the dispute in the same manner? The ICJ, for instance, has a wealth of experience in handling maritime disputes. If two given parties agree to bring a particular dispute to the ICJ, surely the Court would be well able to provide a legal solution to their disputes. However, one important condition precedes this scenario, that is both parties have to be able to consent to the jurisdiction of a dispute settlement body to hear the case. In actual fact, States are not always able to reach such an agreement. For different reasons, a State may wish to continue with existing means of settlement, instead of resorting to third-party settlement. This is, of course, perfectly fine as sovereign States are free to choose whichever means of dispute settlement available to them, as long as it is peaceful in accordance with Article 30 UN Charter and Article 279 UNCLOS. However, in the case that negotiations prolong without any discernible or tangible result, the refusal of one party to give consent to the jurisdiction of a court and tribunal may bring the disputes to a deadlock. This is exactly the situation where the UNCLOS dispute settlement system comes in handy and where it distinguishes itself from other international dispute settlement fora.

As mentioned, the dispute settlement procedures listed under Article 287 UNCLOS are "compulsory". This means that by becoming a party to the Convention, States also give their consent to the jurisdiction of the dispute settlement bodies set out under Article 287. Put another way, a State's consent to UNCLOS tribunals' jurisdiction is given by virtue of being a party to the Convention. Thus, should a dispute arise concerning the interpretation and application of UNCLOS between two State parties of the Convention, any State can unilaterally invoke the dispute settlement procedures without having to take any extra step. Although, as will be analyzed below, the compulsory jurisdiction of the law of the sea tribunals is subject to several limitations, these limitations do not negate the fact that UNCLOS reverses the default position under international dispute settlement. This means that compulsory arbitration and adjudication now become the norm, not the exception. ${ }^{92}$ Given the cardinal principle of international dispute settlement that international courts can only hear a case if the parties have consented to giving them jurisdiction, the default consent given to the jurisdiction of UNCLOS tribunals is a clear advantage over other dispute settlement fora in terms of the availability that it offers to States

\footnotetext{
${ }^{92}$ Bernard H. OXMAN, "A Tribute to Louis Sohn - Is the Dispute Settlement System under the Law of the Sea Convention Working?” (2007) 39 George Washington International Law Review 655.
} 
wishing to use third-party settlement. ${ }^{93}$ This advantage is clear when the jurisdiction of UNCLOS tribunals is compared, for instance, with the ICJ. Even though the ICJ is the principal judicial organ of the United Nations, the mere fact that a State is a party to the UN Charter or the Statute of the ICJ is not sufficient for the ICJ to have jurisdiction over a dispute arising between States parties of the UN. Under Article 36 of the ICJ Statute, in order to recognize the jurisdiction of the Court, States have to conclude a special agreement, become party to a treaty that provides for the settlement of disputes by the Court or file a unilateral declaration recognizing the jurisdiction of the Court. Thus, compared with the UNCLOS dispute settlement system, the extra step required creates additional obstacles for States wishing to make use of third-party settlement.

The UNCLOS dispute settlement system, therefore, can play a useful role in disputes in which one side deliberately avoids any means of third-party dispute settlement. It has to be emphasized that negotiations are, and should rightly be, the first and primary means of dispute settlement for any States. However, in some cases, negotiations can become a shield to guise attempts to avoid peaceful settlement in favour of the use of political, military or economic pressure in order to achieve certain desired outcome. In such cases, the use of third-party settlement proves to be essential to ensure fairness and justice for all those involved. The compulsory jurisdiction of UNCLOS underlies and realizes this goal. The default consent given to UNCLOS dispute settlement bodies ensures that should negotiations fail, another avenue is readily available for peaceful settlement. This was the case, for example, in South China Sea disputes, in which China consistently rejected any efforts to resolve the disputes other than bilateral negotiations. Thanks to the UNCLOS compulsory jurisdiction, the Philippines was able to bring the case to Annex VII arbitral tribunal despite China's rejection of the arbitration.

Another example of the usefulness of UNCLOS dispute settlement in a case involving two States which are unequal in every aspect, albeit not Asian, can be seen in the Chagos Marine Protected Area case. ${ }^{94}$ Prior to bringing the case to Annex VII Arbitral Tribunal, it was reported that Mauritius had contemplated on taking the Chagos issues against the UK before the ICJ. ${ }^{95}$ In

\footnotetext{
${ }^{93}$ Chittharanjan F. AMERASINGHE, Jurisdiction of International Tribunals (The Hague, London, New York: Martinus Nijhoff 2002), 70.

${ }^{94}$ Chagos Marine Protected Area Arbitration (Mauritius v. United Kingdom), Arbitral Award of 18 March 2015, online: <http://www.pca-cpa.org/MU-UK\%2020150318\%20Awardd4b1.pdf?fil id=2899>.

${ }^{95}$ Jon LUNN, “The Chagos Islanders", Standard Notice SN/IA/4463 (House of Commons Library: London, updated 2 June 2010), Kate KELLEND, "Mauritius says may leave Commonwealth in Chagos row" Reuters (7 March 2007), online: $<$ http://uk.reuters.com/article/2007/03/07/uk-mauritius-britain-chagos-idUKL0742404220070307>.
} 
what was allegedly an attempt to preempt Mauritius' intention, ${ }^{96}$ the UK amended its declaration accepting the ICJ's jurisdiction, excluding any dispute involving a current or former member of the Commonwealth. ${ }^{97}$ As a result, Mauritius could not bring the Chagos dispute to the forum it had initially planned. The fact that Mauritius was eventually able to bring the case to a tribunal under UNCLOS attests to the importance of the compulsory jurisdiction of the UNCLOS dispute settlement system for a State wishing to find a way out of their disputes through third-party settlement. Closer to home, Japan recently amended its optional clause declaration accepting the jurisdiction of the ICJ which excludes, inter alias, "any dispute arising out of, concerning, or relating to research on, or conservation, management or exploitation of, living resources of the sea". ${ }^{98}$ This means that if a dispute were to arise between Japan and another State which is also a party to UNCLOS concerning the conservation, management or exploitation of living resources of the sea, the only avenue for third-party settlement left would be that under UNCLOS. In Asia where the majority of States have not accepted the jurisdiction of the ICJ and the reluctance to use international dispute mechanisms is still quite common, at least for non-economic related disputes, the fact that many are parties to UNCLOS opens the door for the possibility of using third-party settlement. This underlies the unique role the UNCLOS dispute settlement can play in the resolution of maritime disputes.

Furthermore, UNCLOS dispute settlement bodies have shown through their case law that they are not hesitant to deliver a decision on issues considered sensitive or thorny. Although the jurisprudence generated by UNCLOS bodies has generally followed the approaches taken created by other international courts, it is also apparent that UNCLOS bodies have been willing to adopt different approaches when called for. As can be seen in the Bay of Bengal maritime delimitation cases, both UNCLOS tribunals for the first time embarked on delimiting the overlapping outer continental shelves even when none of the parties had received recommendations from the CLCS. This approach can be contrasted with that of the ICJ in the Nicaragua v. Honduras or Nicaragua $v$ Colombia cases, in which the Court declined to consider

${ }^{96}$ See Colin WARBRICK, "United Kingdom Materials on International Law" (2004) 75 British Yearbook of International Law 804, Anthony AUST, Handbook of International Law, $2^{\text {nd }}$ ed (Cambridge: Cambridge University Press 2010), 419, Stephen ALLEN, The Chagos Islanders and International Law (Oxford: Hart Publishing, 2014), 284.

972271 UNTS 285. The UK amended declaration broadened the scope of the exclusion to the ICJ's jurisdiction to include not only disputes with current but also with former Commonwealth countries.

${ }^{98}$ Declarations recognizing as compulsory the jurisdiction of the International Court of Justice under Article 36 , paragraph 2 of the Statute of the Court,

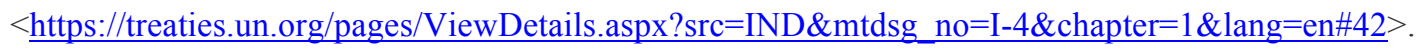


Nicaragua's submission to delimit the outer continental shelf when the CLCS had not yet made a recommendation. ${ }^{99}$ Admittedly, UNCLOS bodies' tasks were relatively easier as, unlike the ICJ cases, the parties concerned did not dispute the scientific evidence proving the existence of entitlements to an outer continental shelf in the Bay of Bengal. They were only divided on the legal interpretation of Article 76 UNCLOS. The decisions, however, suggest that ITLOS and Annex VII arbitral tribunals are not reluctant to be the pioneer in giving unprecedented answers to questions of law. This attitude can also be seen in the Philippines $v$ China awards, where the tribunal answered long-debated questions, including whether a dispute over maritime delimitation and that over maritime entitlement are distinct or what constitutes a rock under Article 121(3) UNCLOS. The Convention, as a result of vast compromises made during the Third Conference on the Law of the Sea, contains many vague and general provisions. This has enabled States to adopt different interpretations and exploitation of the loopholes in the application of the Convention in practice. ${ }^{100}$ The willingness of UNCLOS tribunals not to sidestep thorny and sensitive issues, as did the ICJ in several cases, ${ }^{101}$ will likely be of more assistance to the parties in breaking deadlocks and paving the way for peaceful dispute settlement.

\section{B. The Limitations of the UNCLOS Dispute Settlement System}

Even though the jurisdiction of UNCLOS dispute settlement bodies is compulsory, the design of the UNCLOS dispute settlement itself may pose hurdles to its utilization and ability to contribute to resolving maritime disputes in Asia. First, the setup of the Part XV of UNCLOS creates a legal barrier for States to resolve certain disputes even if there is political will to resort to the

\footnotetext{
${ }^{99}$ David P. RIESENBERG, "Recent Jurisprudence Addressing Maritime Delimitation Beyond 200 Nautical Miles from the Coast" (2014) 18(21) ASIL Insights. Note that in its most recent judgment concerning jurisdiction to delimit the outer continental shelf, the ICJ seemed to have changed its mind and adopted the approach of ITLOS and Annex VII arbitral tribunal. The ICJ confirmed that it had jurisdiction to delimit the outer continental notwithstanding the absence the CLCS recommendation. See Question of the Delimitation of the Continental Shelf between Nicaragua and Colombia Beyond 200 Nautical Miles from the Nicaraguan Coast (Nicaragua v. Colombia), Preliminary Objections, Judgment of 17 March 2016 at 112-14, online: <http://www.icjcij.org/docket/files/154/18956.pdf>.

${ }^{100}$ See Hitoshi NASU, Donald R. ROTHWELL, "Re-Evaluating the Role of International Law in Territorial and Maritime Disputes in East Asia”'(2014) 4(1) Asian Journal of International Law 55.

${ }^{101}$ PHAM Lan Dung, NGUYEN Ngoc Lan, "Some legal aspects of the Philippines v. China under Annex VII UNCLO" in TRAN Truong Thuy, LE Thuy Trang, eds., Power, Law, and Maritime Order in the South China Sea (Lanham, Boulder, New York, London: Lexington Books, 2015) 331.
} 
system. Second, the lack of an effective enforcement mechanism raises concerns regarding the effectiveness of the system in securing compliance with the decisions.

In respect of the design of the system, compulsory third-party procedures are provided only in Section 2 of Part XV, following Section 1 concerning external means of dispute settlement, and subjected to the limitations and exclusions included in Section 3. Section 1 requires that compulsory procedures under UNCLOS should be used only after States have exhausted the means of their choice, including those in other conventions. Furthermore, under Section 3, Article 297 paragraphs (2) and (3) automatically exclude certain disputes from the jurisdiction of UNCLOS tribunals under all circumstances, Article 298 excludes disputes relating to maritime boundary, historic rights, law enforcement activities at sea upon an optional declaration by the State.

The priority accorded to other procedures of settlement over the UNLOS system in Section 1, and the exclusions contained in Section 3 have raised doubts concerning the purported compulsory nature of the dispute settlement system. ${ }^{102}$ One commentator contended that the exceptions and limitations in Section 3, along with the procedural barriers contained in Section 1, create jurisdictional limitations, which in turn create legal uncertainty for the States in deciding whether to use the compulsory dispute settlement procedures. This author further argued that "legal certainty is one of the critical factors in litigation strategy; if there is a fear that litigation may not be successful due to the jurisdictional limitations of the forum, a state is likely to be unwilling to use that forum. ${ }^{, 103}$ Moreover, under Article 288(1) UNCLOS dispute settlement bodies only have the jurisdiction to hear disputes concerning "the interpretation and application of UNCLOS". It follows that disputes that concern territorial sovereignty per se are beyond the reach of UNCLOS tribunals. ${ }^{104}$

\footnotetext{
102 See: Shigeru ODA, "Dispute settlement prospects in the Law of the Sea" (1995) 44(4) International and Comparative Law Quarterly 863; Alan BOYLE, "Dispute Settlement and the Law of the Sea Convention: Problems of Fragmentation and Jurisdiction" (1997) 46 International and Comparative Law Quarterly 37; Christine CHINKIN, "Dispute Resolution and the Law of the Sea: Regional Problems and Prospects" in James CRAWFORD, Donald ROTHWELL, eds, The Law of the Sea in the Asian Pacific Region: Developments and Prospects (Martinus Nijhoff 2012).

${ }^{103}$ Md. SAIFU KARIM, "Litigating Law of the Sea Disputes Using the UNCLOS Dispute Settlement System" in Natalie KLEIN, ed, Litigating International Law Disputes Weighing the Options (Cambridge: Cambridge University Press 2014) 272.

${ }^{104}$ Chagos Marine Protected Area Arbitration, supra note 94, at 221, 230.
} 
The categories of maritime disputes that are excluded from the jurisdiction of UNCLOS dispute settlement bodies by virtue of Articles 297 and 298 are precisely those that are most prevalent in Asia. For example, maritime boundaries disputes between many States in Asia have not been resolved; China, Vietnam, Indonesia, the Philippines frequently quarrel over fisheries, law enforcement activities over fishermen, ${ }^{105}$ while China and Japan over military activities taking place at sea. ${ }^{106}$ At the same time, sovereignty disputes, which are deeply intertwined with maritime issues, occupy a central role in the mind of the State and its people. The UNCLOS dispute settlement system may be of limited use for States in resolving these disputes.

Nevertheless, the Philippines $v$ China case adeptly demonstrates that these exceptions and exclusions in themselves do not render the whole system inoperative. The scope of these exceptions is narrower than the interpretation of may States of Articles 297 and 298. As such, they do not and cannot serve as a blanket to cover all disputes from the compulsory jurisdiction of UNCLOS tribunals. The arbitral tribunal in the Philippines $v$ China case examined each of the Articles 297 and 298 in detail to determine the extent to which they prevent the tribunal from exercising jurisdiction. The Philippines also succeeded in bringing a case against China despite the existence of sovereignty disputes between the two. It follows that the existence of sovereignty disputes and the fact that they fall outside the jurisdiction of UNCLOS bodies does not necessarily render it impossible for States to resort to Part XV. What it does suggest is that States should be mindful that there are limits as to how far UNCLOS tribunals can address the their concerns.

Turning to enforcement and compliance, unlike the ICJ which benefits from an enforcement mechanism through the Security Council as the judicial body of the UN, the dispute settlement mechanism of the UNCLOS does not have a permanent body which can exercise such

105 See, e.g., Keith JOHNSON, Dan DE LUCE, "Fishing Disputes Could Spark a South China Sea Crisis" Foreign Policy (7 April 2016), online: <http://foreignpolicy.com/2016/04/07/fishing-disputes-could-spark-a-south-china-seacrisis/>; Trefor MOSS, "Indonesia Blows Up 23 Foreign Fishing Boats to Send a Message" Wall Street Journal (5

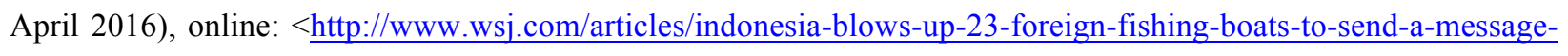
1459852007>; "Philippines detains Chinese, Vietnamese fishermen for suspected poaching” South China Morning Post (17 May 2016), online: < $\underline{\text { http://www.scmp.com/news/china/article/1946185/philippines-detains-chinese- }}$ vietnamese-fishermen-suspected-poaching $>$.

106 Sheila A. SMITH, “A Sino-Japanese Clash in the East China Sea”, Council on Foreign Relations, online: <http://www.cfr.org/japan/sino-japanese-clash-east-china-sea/p30504>; Sam LAGRONE, "Chinese and Japanese Fighters Clash Over East China Sea" US Naval Institute News (5 July 2016), online: $<$ https://news.usni.org/2016/07/05/chinese-japanese-fighters-clash-east-china-sea $>$. 
enforcement function. Nevertheless, since the UNCLOS dispute settlement system came into operation 20 years ago, the majority of the decisions rendered have been complied with. Apart from the recent Philippines $v$ China case, the only other instance in which the respondent State rejected the proceedings for lack of jurisdiction and failed to appear before the tribunal was the Arctic Sunrise case. In this case, Russia rejected the case brought by the Netherlands against it-before both ITLOS for provisional measures and Annex VII arbitral tribunal for the merits - for arresting and detaining the vessels, which were flying the Dutch flag, and its crew. Russia announced that it would not promptly comply with the Order of ITLOS requesting it to immediately release the Arctic Sunrise and allow the non-Russian crew members to leave the Russian territory. ${ }^{107}$ However, it is worth noticing that in the end, Russia eventually implemented all the measures asked by ITLOS. ${ }^{108}$ Even though the release of the vessels and crew was purportedly to comply with Russia' domestic legislations, the ultimate effect was practically the same. This goes to show that the non-compliance rhetoric given by the State does not always reflect its behaviour and action on the ground and that the lack of enforcement mechanism in international law does not necessarily mean non-compliance.

\section{What Prospects for UNCLOS Dispute Settlement System?}

In recent years, many Asian States have actively been seeking ways to resolve their maritime disputes peacefully. States in Southeast Asia, for example, have been negotiating their maritime boundaries for decades and clear progress has been made. ${ }^{109}$ At the same time, several other disputes remain unresolved and have caused rising tension. Apart from the South China Sea, the East China Sea continues to be a scene of constant conflicts between China, Japan and South Korea, and its nature is no less complex that in the South China Sea. ${ }^{110}$

Against such a background, it is worth asking what role the UNCLOS dispute settlement system could likely play in the resolution of these disputes? In order to answer this question,

107 “Arctic Sunrise” (Kingdom of the Netherlands v. Russian Federation), Provisional Measures, Order of 22 November 2013, [2013] ITLOS Rep. 230.

108 "Greenpeace Arctic Sunrise: Russia 'frees protest ship"” BBC (6 June 2014), online: $<\underline{\text { http://www.bbc.co.uk/news/world-europe-27736927> }}$

109 Tara DAVENPORT, 'Southeast Asian Approaches to Maritime Boundaries' 2014 4(2) Asian Journal of International Law 309.

${ }^{110}$ Tatsushi ARAI, Shihoko GOTO, Zheng WANG, eds, Clash of National Identities: China, Japan, and the East China Sea Territorial Dispute, online: <https://www.wilsoncenter.org/sites/default/files/asia china seas web.pdf>; Asian Maritime Transparency Initiative, "East China Sea Tensions: Approaching a Slow Boil”, online: $<\underline{\text { https://amti.csis.org/east-china-sea-tensions/>. }}$. 
factors which motivate the parties to the dispute to resort to third-party settlement and factors which discourage States to do so would have to be identified and weighed against one another.

With regard to the motivating factors, as analyzed above, the compulsory jurisdiction of the UNCLOS dispute settlement bodies is an attractive element when States contemplate which tribunal to bring their dispute to. The default consent given to the jurisdiction of UNCLOS tribunals by virtue of becoming a party to the Convention clearly offers the system an advantage over others which require additional steps to be taken in order to establish the consent of States. With regards to performance, the fact that UNCLOS tribunals are capable of rendering decisions which have been, by and large, positively received by the parties attests to the role that they can play in solving what may deem to be the thorniest and most politically sensitive issues. Moreover, ITLOS and Annex VII arbitral have been utilized for proceedings of different nature, ranging from rendering provisional measures, settling disputes concerning one single issue, such as maritime delimitation, to disputes comprising several complicated, intertwined issues. In short, the clear blessing of the UNCLOS dispute settlement system rests in the assurance that it provides to States that their disputes will not have to go on indefinitely. That consent to jurisdiction has already been given ensures that jurisdiction will, with limited exceptions, be established and that a legal solution will be provided within a specified time frame.

Having said that, the decision to initiate a case before an international court of tribunal is influenced a string of different factors, including the perceived benefits to be gained from judicial settlement, economic incentives, domestic concerns and other strategic consideration, all of which determine the level of political will to resort to third-party settlement. The specific interests that are at stake can obviously only be judged on a case-by-case basis. It is generally agreed, however, that resort to international courts and tribunals by Asian States remains lower that other parts of the world. ${ }^{111}$ An examination of the reasons behind this reality requires an analysis that transcends law, and is, therefore, beyond the limited scope of this paper. However, if there is any wisdom in the saying "If you want to know the future, look the past", one indicator of Asian States' willingness to use the UNCLOS dispute settlement is the views that they expressed during the Third Conference on the Law of the Sea.

Not all Asian States were present at the Third Conference, nor did they all express a view on the compulsory dispute settlement system that was to be established. A brief perusal of the Conference's negotiating texts and other relevant documents shows that among those that did, their stances could be divided into two contrasting groups. The first consisted of States that

\footnotetext{
${ }^{111}$ Simon CHESTERMAN, "The International Court of Justice in Asia: Interpreting the Temple of Preah Vihear Case" (2015) 5(1) Asian Journal of International Law 1; Rodman R. BUNDY, "Asian perspectives on Inter-State Litigation" in Natalie KLEIN, supra note 103 at 148.
} 
vehemently opposed to a compulsory system, including China, India or Indonesia. China believed that the establishment of dispute settlement procedures was a way for super-powers to protect their vested interests and weaken the provisions in the new law of the sea which reflected the interests of third world countries. ${ }^{112}$ Indonesia showed somewhat a lower level of skepticism, saying that it did not rule out the use of compulsory settlement, although it in any case preferred consultation and regional machinery. ${ }^{113}$ Other States, on the other hand, supported the creation of compulsory dispute settlement, including Bangladesh, ${ }^{114}$ South Korea, ${ }^{115}$ Sri Lanka, ${ }^{116}$ Singapore and the Philippines. Both Bangladesh and Singapore stressed the importance of compulsory settlement to smaller countries as a powerful means to help them "prevent interference by large countries" and "necessary in order to avoid political and economic pressures". ${ }^{117}$ Past performance is, of course, not necessarily indicative of future results, and the opinions of Asian States during the Third Conference in the 1970s are certainly not determinative of their attitude or approach to the utilization of the UNCLOS dispute settlement today. However, one cannot but see a certain level of alignment between the opinions of some States expressed during the Third Conference and their legal actions, or lack thereof, under the auspices of UNCLOS in recent years.

\section{CONCLUDING REMARKS}

Asia has not traditionally been an active scene of international litigation for sovereignty and maritime issues. Negotiations remain the favoured means of dispute settlement and there is no obligation for States to bring their disputes to an international court or tribunal.

However, in light of the positive impacts that the case law of UNCLOS tribunals have brought to each State party as well as for the region, it is argued that UNCLOS dispute settlement system can play a meaningful role in the process of dispute resolution. The outcome of the cases with which ITLOS and Annex VII have dealt involving Asian States shows that adjudication and arbitration do not have to be utilized at the expense or exclusion of other means of settlement, not least with negotiations. The UNCLOS dispute settlement system, with its compulsory jurisdiction, offers States a readily available alternative to situation where

112 Official Records of the Third United Nations Conference on the Law of the Sea, vol. V (United Nations publication, Sales No. E. 76. V. 8)

${ }^{113}$ Ibid., 41 at $71-72$.

${ }^{114}$ Ibid., 41 at 63.

${ }^{115}$ Ibid., 28 at 69

${ }^{116}$ Ibid., 17 at 39.

${ }^{117}$ Ibid., 10 at 24. 
negotiations become symbolic than real, which only leads to stagnation or regressions. UNCLOS tribunals have made significant contributions to resolving thorny disputes between Asian States, clarifying the legal framework for the conduct of the parties and facilitating cooperation amongst countries in the region. The ability of UNCLOS tribunals to bring a peaceful solution to the disputes and more broadly to the region also shows that maritime boundary disputes are not necessarily destined for indefinite purgatory that has all too often been the norm in Asia. ${ }^{118}$

${ }^{118}$ Jared Bissinger (n 22). 